\title{
Christian Gottlob Heyne and the changing fortunes of the commentary in the age of Altertumswissenschaft
}

Book or Report Section

Accepted Version

Harloe, K. (2015) Christian Gottlob Heyne and the changing fortunes of the commentary in the age of Altertumswissenschaft. In: Kraus, C. S. and Stray, C. (eds.) Classical Commentaries: Explorations in a scholarly genre. Oxford University Press, Oxford, pp. 435-456. ISBN 9780199688982 Available at http://centaur.reading.ac.uk/39805/

It is advisable to refer to the publisher's version if you intend to cite from the work. See Guidance on citing.

Publisher: Oxford University Press

All outputs in CentAUR are protected by Intellectual Property Rights law, including copyright law. Copyright and IPR is retained by the creators or other 
copyright holders. Terms and conditions for use of this material are defined in the End User Agreement.

\section{www.reading.ac.uk/centaur}

\section{CentAUR}

Central Archive at the University of Reading

Reading's research outputs online 


\title{
Christian Gottlob Heyne and the Changing Fortunes of
}

\section{the Commentary in the Age of Altertumswissenschaft}

\author{
Katherine Harloe
}

This chapter seeks to explore issues raised by the major commentaries on Tibullus, Virgil and the Iliad that came from the pen of Christian Gottlob Heyne (1729-1812). For a long time Heyne was neglected within classical scholars' understanding of their own history, yet in his own age he was something of a European intellectual celebrity, and even at the end of the nineteenth century Friedrich Paulsen could identify him as 'indisputably the leader in the field of classical studies in Germany during the second half of the eighteenth century' (1885: 441). Heyne's claim to significance stems from the power he exercised over classical education and appointments during his half-century long tenure of the chair of Eloquence and Poetry at the Georgia Augusta (the University of Göttingen) and directorship of its famous Philological Seminar; from his influence on literary and cultural figures such as Goethe, the brothers Schlegel and Wilhelm von Humboldt; and from his important work in the fields of ancient history, myth and ancient art. These areas of his scholarship have received attention from scholars in recent decades (see for example Leventhal 1986, 1994; Graf 1987; Vöhler 2002; Fornaro 2004; Clark 2006; Heidenreich 2006; Legaspi 2008, 2010, 53-78; Harloe 2013); yet, with relatively few exceptions (Atherton 2006: 74-88; Heidenreich 2006, Chapter 2; Haynes 2010: 425-6), his editions and commentaries on ancient authors have been less discussed. ${ }^{1}$ This is surprising, as Heyne's commentaries were a central part of his intellectual

\footnotetext{
${ }^{1}$ An exception is his Pindar edition of 1798, discussion of which would merit an article of its own. See Wilson in this volume for a discussion of eighteenth-century Pindar scholarship. The state of scholarship is reflected in Grafton's recent encyclopaedia article on Heyne (2010 KCH: Is this OK
} 
endeavours, and were responsible above all for securing his reputation among his contemporaries.

Although he did produce occasional editions of prose authors (Epictetus, pseudoApollodorus, Proclus), Heyne focused in the main on Greek and Latin poets - and on the very authors, such as Pindar, Virgil and Homer, who had come to play a central role in the classical education and aesthetic debates of his own day. This is characteristic of his scholarship, for as Grafton and others have emphasised, Heyne was an innovator, who sought — and largely succeeded — in adapting traditional humanistic education to the demands of a modern and practical academic institution, an Enlightened era, and a developing conception of classical studies as the multidisciplinary and comprehensive study of antiquity ('Altertumswissenschaft'). At the same time, his work remains in some respects a product of 'the skills - and the encyclopaedic knowledge of Baroque scholarship' (Grafton 2010: 436). This characterisation of Heyne as in certain ways a transitional figure is crucial to appreciating his efforts to update the commentary format to the demands and preoccupations of his age.

\section{Scholarly formation and predecessors: Ernesti and Gesner}

It is impossible to understand the principles and ambitions that motivated Heyne's commentaries without relating them to the strand of reforming, new-humanistic pedagogy to which he was exposed during his student years in Leipzig. Two older scholars, Johann Matthias Gesner (1691-1761) and Johann August Ernesti (1707-1781), are often grouped

now? Would it avoid ambiguity to say 'Grafton's 2010 encyclopaedia article on Heyne’?

Otherwise people might read as a reference to Heyne 2010?), which allows only half a sentence to his 'innovative editions'. 
together with Heyne as precursors of that neo-Hellenic neo-humanism formulated towards the end of the century by Goethe, Humboldt and Wolf. They had strong connections with each other and with Leipzig: Gesner worked from 1730 to 1734 as Rector of the city's famous and historic Thomasschule, where Ernesti served as his deputy from 1731. When Gesner departed to take up the chair of Eloquence and Poetry at the newly founded University of Göttingen, Ernesti inherited the school's direction. In 1742 he was appointed extraordinary professor of Philology at the university, from which he proceeded to the chairs of Eloquence (1756) and Theology (1759). ${ }^{2}$ Heyne studied in Leipzig between 1748 and 1752, where he is known to have attended Ernesti's lectures and to have been admitted to his fee-paying class on Cicero. He was eventually to succeed Gesner at Göttingen, where he would extend and transform the philological seminar his predecessor had established and through it exercise a decisive influence over the formation and appointment of classical teachers in schools and universities to the close of the century.

Gesner and Ernesti were pedagogical innovators, united by dissatisfaction with conventional approaches to instruction in classical languages and a shared vision of an alternative. Gesner (who was the senior and in many ways the more important of the two) outlined his programme in a series of writings from both the Leipzig and Göttingen stages of

\footnotetext{
${ }^{2}$ On Gesner see Bursian 1883: 387-93, Schindel 1964, Sandys 1908: 5-9, Friedrich 1991, Legaspi 2010: 61-8. On Ernesti see Blaschke and Lau 1959, Bursian 1883: 400-3, Paulsen 1885: 434-40, Sandys 1908: 11-14; Pfeiffer 1976: 171. Ernesti paints a memorial portrait of Gesner in an open letter addressed to David Ruhnken (1762: 307-42). The most rewarding discussion of both is still Paulsen's chapter on 'Die Universität Göttingen und die neuhumanistische Philologie und Gymnasialpädagogik' (1885: 424-51). Pfeiffer is scant on Ernesti and utterly inadequate on Gesner, whom Sandys 1908: 5 calls 'one of the greatest scholars in the eighteenth century'.
} 
his career. ${ }^{3}$ Perhaps the clearest statement of intent is contained in his Preface to an edition of Livy, first published in 1735 and reprinted a decade later in his Opuscula minora. Here, Gesner inveighed against the practice of the schools of his day, where, rather than opening students' eyes to the literary beauties and historical meanings of classical works, masters spun out tedious hours dissecting sentences, parsing individual words and phrases and directing their charges to copy them out over again. The result was a class of young men who hungered for the latest instalment of the adventures of a Telemachus, Crusoe or Gulliver but shrank from Homer, Virgil, Suetonius and Curtius, authors Gesner judged 'non minus iucundos' and in many cases more instructive than their modern counterparts (1745: 292-5).

In place of this deadening mode of instruction, which he termed 'lectio stataria', Gesner recommended 'lectio cursoria', a method which he claimed to have tried out to good effect in the Thomasschule. Its aim was to enable students to read canonical authors in their entirety and to awaken them to their works' distinctive beauties (Legaspi 2010: 64-6, Atherton 2006: 79-80). Rather than being detained by discussion of hard grammatical problems and obscure vocabulary, Gesner's class deferred such questions to later discussion, focusing instead on fluent reading of the work as a whole:

Legitur autem ita, vt diligenter quidem attendatur ad vocum tum simplicium significatus, tum coniunctaturum, vt non negligatur, si quid eleganter, si quid proprie, si quid concinne, si quid splendide dictum videatur; vt ipsae figurae quoque orationis demittantur ad animum, et familiares tractatione et cogitatione reddantur. (Gesner 1745: 299-300)

\footnotetext{
${ }^{3}$ See for example his school ordinances for Electoral Hanover (Gesner 1738) and the various prefaces and essays collected in Gesner 1756.
} 
Cursory reading allowed room for historical as well as literary interpretation, as is revealed by Gesner's list of questions and topics to be addressed by the commentator. ${ }^{4}$ The result, so he enthused, would be a form of classical learning which would not only be useful, in that it would augment the mind by good counsel and equip it for the conduct of both public and private business, but which would also increase the reader's 'voluptas' by awakening him to the literary and aesthetic merits of ancient authors.

Gesner's edition of Claudian, which has sometimes been identified as the model for Heyne's Virgil, provides a good example of the kind of commentary generated by such an approach. ${ }^{5}$ Although Gesner declared that part of his purpose was the provision of a thoroughly revised text, he saw its main value as lying in the 'adnotatione perpetua ... quo intelligi, \& ad vitae aliquem usum transferri etiam a mediocriter doctis vel occupatis, sine multo labore aut discursu ad alios libros, possint' (1759: x-xi). Gesner's text for the most part followed the first edition of Nikolaas Heinze [Nicolaus Heinsius] (1650), adopting the readings of Heinze's second edition, of earlier published versions and other scholars' conjectures eclectically. Heinze's philological notes were abbreviated and relegated to an apparatus, and instead Gesner concentrated upon explicating 'quae vel ab historia vel ab alia

\footnotetext{
${ }^{4}$ 'In historia autem vel vera vel conficta studiose obseruatur, quis, quid, quo tempore, quo consilio praesertim, egerit, quibus adiumentis et quasi instrumentis sit usus, quae impedimenta et quomodo remouerit, quid effecerit denique, quemque facti sui fructum tulerit? quomodo superiora his quae sequuntur cohaereant, et haec ex illis quasi orta sint? videaturne ea narrare scriptor, quae sic fieri potuerint, et aliorum etiam fide nitantur; an dicat, quae conciliari, vel inter se, vel cum aliis rebus, de quibus certo nobis constat, non possint? In poëtis praeter haec modo dicta, artis etiam vestigia, et picturas rerum, ingeniorum, morumque et perturbationum descriptiones, persequitur' (1745: $300)$.
}

${ }^{5}$ Anon. 1767: 249; Sandys 1908: 6; Heidenreich 2006: 123. 
parte eruditionis repetita praesto esse debent intellecturo poëtam, doctum sane \& nihil temere dicentem, quod non vel eruditum lectorem postulet, vel faciat' (xiv).

Typical of Gesner's approach is his commentary on the opening lines of Claudian's epithalamion for Honorius and Maria:

Hauserat insolitos promissae virginis ignes

Augustus, pronoque rudis flagrauerat aestu.

(Claud. Nupt. Hon. et Mar. 1-2)

On these lines, Heinze confines himself to citing authorities and adducing parallels from Horace and Ovid in order to justify his reading of 'pronoque' against the vulgate 'primoque'. 6 His second edition, to which Cornelis Schrevel had added the notes of earlier commentators, adds three more interpretative comments on line 1 from the earlier seventeenth-century edition of Caspar von Barth:

1. Hauserat] ex Maronis illo adumbratum: At regina, graui jamdudum saucia cura,

Vulnus alit venis, \&c.

Promissae] Est fictio Stilichonem adulantis: Siquidem aliis artibus hoc matrimonum constructum

Ignes] Amorem, qui igni comparatur

${ }^{6}$ 2. Augustus, pronoque rudis] Sic Lucensis \& caeteri plerique cum primis editionibus. neque aliter prim. Vatican. \& Oiselianus pro diversa lectione. quod minime explodi à Barthio debuit. apud Horatium: Lycus in asperam Declinat Pholoen. \& apud Nasonem: Paulatim declinat amor. unde liquet, cur noster pronum aestum dixerit. Vulgati primoque (Heinze--Schrevel 1665: ad loc.). 
Gesner reduces Heinze's textual notes to a line of the apparatus ('primoque vulg. pronoque ex libris optimis Heins'), and dispenses with Barth's rather pedestrian observations. His comment -

Hauserat ex conspectu, oculis, gestu, virginis, amoris ignes. Rudis novitatem affectus indicat; pronus subita incrementa, \& impetum vehementem, qualis est rerum gravium, dum labuntur singulis momentis novos impulsus ex aucta geometrica ratione pondera accipientium. (1759: 133)

- demonstrates his concern for sensitivity to the flow of language and to its literary and aesthetic qualities, the priorities set out for 'lectio cursoria' in his Preface to Livy.

Elsewhere, Gesner did see fit to engage in more extensive antiquarian and scholarly observations. These are particularly frequent in the case of De Raptu Proserpinae, where the poem's mythological, astrological, linguistic, geographic and literary allusions invited widerranging commentary. They are not, however, confined to De Raptu, as Gesner's note on De consulatu Stilichonis III.135 shows. Heinze had seen no need to comment on the transmitted line ('[Roma] Quae septem scopulis zonas imitatur Olympi’); the 1665 variorum edition nonetheless includes notes of Barth ('Tot numero zonas statuunt nonnulli, alii quinque solas') and Étienne de St Clavière ('Fuit etiam Romae septizonium, index forte septem planetarum'). In place of these, Gesner points out the contradiction between the seven zones or regions of the world mentioned here and the five Proserpina embroiders on her tapestry (Rapt. Pros. I.258) and launches into a longer discussion, citing various Greek sources, of the relation of this to Orphic belief (Gesner 1759: 384). The digression reflects Gesner's own scholarly interests, for he was at the time working on an edition of the Orphic texts. It nevertheless maintains relevance to the passage at hand and is both more informative than Barth and more relevant than Clavière. Characteristically, Gesner ends by drawing general conclusions about 
his author's character and style: 'Doctum esse poëtam nostrum, Alexandrinum, Cosmica doctrina imbutum, \& $\& \mathrm{o} \lambda v \mu \alpha \theta i ́ \alpha \varsigma$ ostentatorem, constat.'

Ernesti's programmatic writings as well as his classical criticism reveal him to have been a partisan of Gesnerian methods. ${ }^{7}$ He placed somewhat more emphasis upon textual scholarship than Gesner: in his Tacitus of 1752 he boasted of having consulted more manuscripts and early printed editions than anyone since Lipsius and included a fairly lengthy preface with descriptions of each (1801 [1773]: vii-lxxvi). It is largely on account of the Tacitus that Ernesti is cited by both Timpanaro (2005: 73-4) and Kenney (1974: 97) as an example of eighteenth-century recognition of the importance of a genealogical approach to the sources. Heyne, too, praises him in these terms in the Preface to his Homer, 'Atque hoc est inter Ernestii, immortalis viri, merita praecipua, quod criticorum studia ad saniorem rationem et diiudicationem reuocauit, cum in tota opera, scriptoribus classicis adhibenda, tum in codicum et editionum auctoritate, dignitate et usu expendendo' (1802 [1]: xxxiv-xxxv). In his own day, however, Ernesti was known primarily for his superlative Latinity, as well as for his editions and commentaries on canonical authors such as Homer and, especially, Cicero. By his own admission a follower of Gesner, Ernesti did not fare as well in the assessments of later scholars. Sandys' verdict is typical: 'Superficial as a writer, but intelligent as an expositor, Ernesti has long been over-rated' (1908: 13).

\section{Heyne's Tibullus (1755)}

\footnotetext{
${ }^{7}$ See for example Ernesti's polemical 1738 Prolusio, qua demonstratur maius utiliusue esse latinos auctores intelligere, quam probabiliter latine scribere, et plerumque illud non posse, qui hoc possit (1794: 306-21), with Heidenreich's discussion (2006: 40-1), and the generous acknowledgment of Gesner's inspiration in the Preface to his Cicero (1737). After his elevation to the chair of Theology in 1759, the centre of gravity of Ernesti's output moved away from pagan authors.
} 
Heyne's lifelong adherence to Gesnerian and Ernestian principles is revealed in his comments about his own schooldays. In a memoir published posthumously in the 1813 biography compiled by his son-in-law, Arnold H.L. Heeren, he dismissively characterizes the learning by rote enforced upon him by the masters at the local Lateinschule as 'ganz der ehemalige Schlendrian, lateinische Vocabeln, Exponiren, Exercitien; Alles ohne Geist und ohne Sinn' (Heeren 1813: 15). He is particularly scathing about the conception of classical learning forced upon him upon him by Sebastian Seydel, a local priest who offered somewhat haphazard financial support to the young scholar and - to Heyne's chagrin-accompanied this with instruction in humaniora:

In his youth he had learned to compose Latin verses; Erasmus' de civilitate morum was hardly put to one side when I was introduced to Latin verse composition; all this before I had read any authors, and had amassed only a small vocabulary for myself. In addition the man was fierce and stern . . . he had the rigidity and obstinacy of an old bachelor, and with it the vanity to suppose himself a good Latinist and, what is more, a Latin poet, and thus a learned minister. ${ }^{8}$

Only the arrival, in Heyne's final year, of one of Ernesti's pupils afforded Heyne 'a foretaste of something better' (18).

\footnotetext{
${ }^{8}$ Er hatte in seiner Jugend lateinische Verse machen gelernt; kaum war ERASMUS de civilitate morum auf die Seite gebracht so ward ich zum lateinischen Versmachen angeführt; Alles dieses ehe ich nocht Schriftsteller gelesen, oder nur einigen Wortvorrath mir verschafft hatte. Der Mann war dabey heftig und streng ... er hatte das Steife und Eigensinnige eines alten Hagestolzen; und dabey die Eitelkeit, ein guter Lateiner, und, was noch mehr ist, ein lateinischer Versmacher, und folglich ein gelehrter Geistlicher, seyn zu wollen (Heeren 1813: 12-13).
} 
If such attitudes show Heyne's enduring loyalty to his teachers, his efforts at editing and commenting on the ancients were to move beyond them. This is apparent from the first major commentary that came from Heyne's pen, which was completed before he became a university professor. Heyne's Tibullus was first published in Leipzig in 1755 and was to go through three subsequent editions over the following half-century, culminating in the posthumous revision completed by Wunderlich and Dissen (1817). Heidenreich (2006: 64) reports that the edition was undertaken at the request of a bookseller; in the Preface, however, Heyne confesses to a strong personal fondness for the poet, to whom he had been accustomed to resort amid the trials and tribulations of his youth (1755: 15). Much of the 1755 Preface comprises an impassioned defence of the poet against those magistri who considered him unsuitable for classroom use. In rollicking, Gesnerian mode, Heyne inveighs against the narrowness of a curriculum and a mode of instruction that does nothing but turn out individuals who, even if 'liberalis' and 'honestus' by nature, become so deadened and boorish by instruction that they are unable to be of service to themselves or to others; and defends the teaching of Tibullus and the other elegists on the grounds of their softness and sweetness of spirit, their polished Latinity, and the high breeding that renders them good subjects for emulation (9-10).

Some of this is traditional: Heyne's praise of Tibullus on the grounds of 'puritate, facilitate et nativa aliqua elegantia' (13) recalls Quintilian's famous ‘tersus atque elegans' (Inst.10.1.93). Yet other touches reveal Heyne's self-consciousness as a citizen of the Age of Enlightenment. Thus we are told that those who devote themselves exclusively to the study of 'seueriores scriptores' develop over time a 'rusticitas et insuauitas' 'quae tamen, nostra inprimis aetate, omnium animos nobis abalienare, et a potentiorum aditu excludere solet' (1755: 9, emphasis mine), and that the reading of the elegists may help one to understand more recent love poetry, especially in Italian and French, without knowledge of which 'nemo 
facile nostra aetate elegans et humanioribus litteris cultus homo haberi soleat' (12-13, emphasis mine). There are hints here of the up-to-the minute education in practical matters and Enlightened sociability for which Heyne's future institution of Göttingen was becoming known.

Yet Heyne had higher ambitions than to produce a Tibullus in usum scholarum. His edition also presents a thorough reworking of the Tibullan text, grounded in a reconstruction of the 'family and stock' of manuscripts and early printed editions down to his own day. ${ }^{9}$ By the time of his second edition in 1777 , Heyne was able to boast that he had inspected a copy of every extant printed version save the princeps; yet it was what he did on the basis of his critical researches that appears innovative by comparison with of his time.

Perhaps the most obvious example of this is the way in which Heyne deals with variae lectiones, the collation of which formed a traditional (and often lengthy) part of the early modern edition of a classical text. Joan van Broekhuizen's edition (1708) represented the pinnacle of this approach applied to Tibullus; it was sharply criticised by Heyne, who condemned such heapings up of blind erudition as very far from 'quae boni interpretis munus postularet' (1817: xxiii [1777 Preface]). Heyne's arguments against the practice are clearly and carefully articulated and rest on historical grounds. After suggesting that Tibullus' text was very likely damaged in antiquity (perhaps during the Great Fire of Rome), Heyne argued that the popularity of Tibullus' poetry both within antiquity and during the Renaissance would have led learned men and poets to strive to complete its lacunae by their own talents. The regrettable consequence was that many of the variant readings preserved in early printed editions, far from representing the tradition of now lost manuscripts, were interpolations

\footnotetext{
9 'prosapia ac stirps lectionis Tibullianae' (Heyne 1817: xxvii). The discussion is presented in the 1755 edition as section 9 of the Preface; in subsequent editions as a separate essay 'De Tibulli lectione per libros scriptos et prelo excusos propagata, adeoque de Tibulli codicibus et editionibus'.
} 
likely to be stem 'e viri alicuius docti ingenio' (1817: xviii, xxiv [1777 Preface]). Little store could be set by them, and Heyne chose to found his edition upon that of Giovanni Antonio Volpi (1749) rather than Broekhuizen, precisely because Volpi had presented a more conservative text than many of his predecessors (1817: xxiv-xv [1777 Preface]). Heyne's decision to return to the readings of the earliest printed editions did not stem from blind faith in the authenticity of the oldest examplars; rather Heyne's textual discussion shows him thinking carefully and historically about questions of transmission. ${ }^{10}$

Equally interesting, and more significant in relation to questions of commentary, were the arguments Heyne levied against the notorious transpositions of verses and sections introduced into Tibullus' text by J. J. Scaliger. For Heyne, consideration of the working methods of scribes rendered such dramatic changes implausible. Although it was not entirely unknown to find whole pages of manuscripts being transposed, 'tamen incredibile est, in eodem carmina ita laxatos esse versus, ut modo ex extremis in principia, ex his in medium, ex hoc in utrumque locum alii et alii disiecti sint, et quidem ita, ut, quod, nisi data opera, et magna cum arte, fieri vix potuisset, sensum qualemcunque constituant' (1817: xviii-xix [1777 Preface]). Heyne argued, moreover, that Scaliger's attempts to rearrange Tibullus' verses into a more logical order showed a fundamental lack of sympathy with the nature of elegy, in which it is the heart and not reason that speaks. The elegiac couplet, in which the unit of sense is often completed at the close of the distich, is particularly well suited to the expression of tortured and staccato emotions:

Immo vero in hoc eius ingenium et natura continetur, ut animi commoti ac perturbati sensus et affectiones seu molliores seu ex graviore impetu iam remissas et subsidentes exprimat. In hoc regnat; in hoc tota est, hoc

\footnotetext{
${ }^{10}$ Heyne's verdict has been upheld by later editors; see, for example, Maltby 2002: 21.
} 
praecipuum argumentum sibi tractandum sumit, neque temere ad alia avocari debet. (1817: xx [1777 Preface])

Heyne's arguments here show the stamp of the broader literary and aesthetic criticism of his era, for a footnote cites Boileau's proclamation in his Ars poétique that 'il faut, que le coeur seul parle dans l'Elegie'. Yet his arguments about the distinctiveness of the elegiac register also show a historicist sensibility, anticipating wider-ranging arguments about differences between literary and sub-literary registers advanced by partisans of August Boeckh in the famous nineteenth-century Methodenstreit with Hermann. ${ }^{11}$

It is Heyne's textual discussion that has earned his Tibullus the greatest praise from scholars. Early reviewers congratulated him for having undertaken the most thorough investigation of the textual tradition to date; in the twentieth century, Sebastiano Timpanaro singled Heyne out for his appreciation (relatively rare in the eighteenth century) of the need to study manuscripts genealogically, as well as his sharp awareness of the phenomenon of contamination (Anon. 1755: 411; Timpanaro 2005: 74). Yet Heyne refused to allow these important critical discussions to impede the clarity of his text and commentary: major philological discussions were divided between the prefatory essay and some 265 pages of 'observationes', at the back of the volume, while pedagogical-expository 'notae' were placed beneath the text in a running commentary aimed at guiding the less expert reader on grammatical points, explaining historical and mythological allusions, and adducing parallels drawn primarily from Propertius, Catullus and Ovid. By such an arrangement, Heyne sought to please both scholars interested in critical matters and those younger readers who required only concise explications of difficult phrases and guidance as to the poet's peculiar venustates. His services to Tibullus were recognised by the reviewers: it was very likely Gesner himself who commended the book as having 'all the characteristics of a perfect

\footnotetext{
${ }^{11}$ See in particular Most 1997: 355-7.
} 
edition' and praised Heyne for being the first to provide 'the conveniences . . . that more than one category of reader might wish for' (Anon. 1755: 411, 409). Most importantly for Heyne, it was primarily on the basis of this edition that Ruhnken was to recommend him a few years later for Göttingen's vacant chair of Eloquence and Poetry. ${ }^{12}$

\section{Heyne's Virgil (1767-1775)}

A similar attempt to balance the needs of different audiences may be seen to have motivated Heyne's Virgil, by far the most celebrated of all his commentaries. The work far outstripped the hopes of its publisher, who had approached Heyne in summer 1764 with the request to produce an updated edition for school use. ${ }^{13}$ Before accepting the invitation Heyne consulted with Ruhnken, who had for some time been urging him to cement his claim to be the German Bentley by following up his Tibullus with editions of other Latin poets and who counselled him to demand a period of time sufficient to produce a work that might satisfy scholars as well as students. ${ }^{14}$ As Wolf-Hartmut Friedrich (1980: 20) has noted, the invitation to work on Virgil came at a fortuitous moment. In 1763 Heyne had succeeded Gesner in the chair of Eloquence and Poetry at Göttingen: a position which, in his own estimation, demanded a certain celebrity of its holder. ${ }^{15}$ Although his Tibullus (together with the Epictetus of 1756) had demonstrated sufficient promise to secure him a university post, he now needed to make

\footnotetext{
${ }^{12}$ The story of Ruhnken's recommendation of Heyne upon himself turning down the offer of Gesner's former chair is well known; see Heeren 1813: 73-82.

${ }^{13}$ The connection was facilitated by Ernesti; see Heidenreich 2006: 123.

${ }^{14}$ Ruhnken to Heyne, 18 July 1764, in Friedemann 1828: 668-70.

${ }^{15}$ Heyne to Winckelmann, July 1763, in Rehm 1957: 95.
} 
his name with a work appropriate to his new standing. What more suitable than a definitive edition of the princeps poetarum $?^{16}$

Heyne's preface makes it clear that he was staking his main claim to renown on the commentary rather than criticism. The text of his first edition followed that of Heinze, in Burman's revision (1744):

non quod multa loca in Virgilio adhuc aut mendo aut mendi suspicione laborare existimem, verum quoniam innovatio omnis in textu non modo periculi et dubitationis habet plurimum, verum etiam, dum subinde nova exemplaria discrepantia infertur, ea res plus plus molestiae et taedii quam fructus et utilitatis affert. (1787-89 I: ix [1767 Preface])

As with the Tibullus, then, Heyne preferred to adopt an earlier editor's text unaltered and reserve his more weighty critical and philological disagreements for notes. The majority of the preface is given over to Heyne's lucid explanation of his conception of the commentator's task. Complaining that previous commentators have heaped up useless erudition in such a manner that the reader's mind is constantly diverted from consideration of the poem in hand, he asserts that:

Caeterem eam legem et regulam, quae omnibus interpretibus proposita esse debet, ut nihil, quod luce aliqua indigeat, cum ad illustrandum difficile sit, omittant ac praetereant, nihil, quod satis habeat, alienis luminibus affusis offuscent et obscurent, nunquam ex oculis dimisi, atque ea adeo industria et cautione me illud assequutum esse spero, ut, si non raram doctrinam,

\footnotetext{
${ }^{16}$ See Atherton 2006: 77, who argues that in turning to Virgil, Heyne chose the school text par
} excellence in order to furnish a model of how to comment upon a ancient author. I do not agree with Atherton that Heyne (even inadvertently) denigrates Virgil in favour of Homer in the course of his critical discussions. 
exquisitas observationes, severas in alios stricturas attulerim, at utiles tamen commentarios in poetarum principem videri debeam, in quibus ea proposita sint, quibus eius lectio adiuuvari, commendari, et, si non omni molestia liberata, at cum voluptate aliqua coniuncta, videri possit. (Heyne 1787-89 I: vii [1767 Preface])

This goal of facilitating an informed, yet pleasurable reading experience led Heyne to privilege observations of two main kinds, besides offering the less experienced reader grammatical help. The first, which Heyne declares to be particularly necessary in the case of this 'doctissimus poeta', are explications of particular points of antiquarian, literary or historical learning, such as the identification of passages that allude to mythical or historical events or that imitate Greek models. Heyne's rationale for including such discussion was historicist: 'Nisi enim vita, conditio, fortuna auctoris, et publica rerum facies, quam ipse ante oculos habebat, cum scriberet, nota sit, multa in unoquoque scriptore obscura nec satis expedita manere necesse est' (1787-89 I: iv [1767 Preface]). Careful attention to political and historical context is evident throughout, for example in Heyne's dismissal of the longstanding association of the fourth Eclogue with the birth of Jesus and his lengthy justification of the alternative suggestion that it was composed to commemorate the peace of Brundisium, the marriage of Octavia and Antony, and the birth of Marcellus (Heyne 1787-89 I: 66-70). ${ }^{17}$ Also noteworthy, given Heyne's growing reputation as an expert on ancient art, are the relatively frequent notes in which he directs his readers to the consideration of ancient statues, reliefs and gems. For example, his fairly lengthy comment on Eclogue 6.13ff. lists numerous ancient visual representations of recumbent Sileni and satyrs published in well-known compendia. These include an engraved gem from the Saxon craftsman Philipp Daniel Lippert's

\footnotetext{
${ }^{17}$ Of course, the date and context of Eclogue 4 still form a topic of considerable debate among commentators. For an interpretation similar to Heyne's, see Slater (1912).
} 
Dactyliotheca, a modish publication with which Heyne himself had been involved. While it was somewhat unusual to find this kind of note in a commentary upon a Latin author, their content is familiar from the world of early modern erudition.

A further, and significant, concession to the demands of traditional scholarship is seen in Heyne's decision to include a comprehensive survey of variae lectiones. These result in a work that looks rather more crammed on the page than the Tibullus, as the exegetical notes foregrounded in that work are relegated to third place, beneath an apparatus which records disagreements with and, fairly frequently, enters into critical refutation of earlier editors. ${ }^{18}$ Yet Heyne insists that even these are included for sound pedagogical reasons: since it is Virgil above all who is used to teach the elements of criticism, it will be useful for trainee critics to have before them a record of all the errors of scribes and learned men. This emphasis on educational ends is reminiscent of the Tibullus, and the continuities become even more apparent with Heyne's announcement of the second emphasis his commentary will pursue:

Cum Virgilius is sit, in quo legendo magna iuuenilium studiorum pars consumi soleat, eo quidem consilio, dummodo multi id sibi propositum haberent, ut ad adolescentum ingenia polienda, ad sensum et gustum pulchritudinis acuendum, ad iudicium de omnibus iis, quae ab arte et ingenio elaborata et expressa oculorum animique sensui subiici possunt, informandum valere illa lectio et vim habere debeat; feci id, quod in alio poeta . . . non mihi faciendum esse putarem, ut non modo ad ea, quae difficilia ad intelligendum et

\footnotetext{
${ }^{18}$ There is some differentiation in terms of layout, for unlike the philological discussions the exegetical commentary is presented two columns per page. This makes it fairly easy to differentiate between sections, but the overall result is that fewer lines of text are presented on each page: an impediment to cursory reading.
} 
obscura sunt, verum ad illa etiam legentium animos aduerterem, quae pulchra in poeta et praeclara insignique aliqua venustate nobilitata sunt, ut iisdem, in aliis poetis, siue obseruandis ac deprehendis siue diiudicandis, adsuescerent. (1787-89 I: viii [1767 Preface])

In addition to its scholarly pretensions, then, Heyne's Virgil proposed to continue and extend the aestheticizing criticism of ancient authors pioneered in his Tibullus. The edition was intended to cater to two audiences: scholars (or scholars-in-training) and those young men who were turning to the classics in in the 1760s the hope of an education in nobility of thought and taste.

Like Gesner before him, Heyne maintained that the key to such interpretation was leading the reader to an understanding of the author's peculiar beauties, within an appreciation of the character of the text as a whole. Beyond developing his readers' understanding of Virgil's 'verba ac sententiae', Heyne aimed at educating them as to the 'ratio et indoles cujusque carminum generis' (1787-89 I: 3) and calling their attention to the distinctive aesthetic qualities he attributes to Virgil: doctrina, iudicium, elegantia, suauitas, dignitas et ornatus orationis. ${ }^{19}$ These are frequently highlighted in Heyne's notes on individual passages (for example, the detailed analysis of the opening of the Georgics, which he reckons 'inter partes carminis ornatissimas ac splendidissimas ${ }^{20}$ ), but also in discursive

\footnotetext{
${ }^{19}$ These qualities are expounded at length in 'De carmine epico Virgiliano', the first of two introductory essays to the Aeneid (Heyne 1787-89 I: xv-liv).

${ }^{20}$ Heyne 1787-89 II: $190-1$; see too his discussion of Aeneas's plea to Dido to 'Desine meque tuis incendere teque querelis' (Aen. 4.360), where he cites the (admittedly rather slight) parallel of Iliad 9. 608-9 before exclaiming 'quam opportune positum! commovere, luctu, dolore et ira exasperare' (Heyne 1787-89 II: 494). As Friedrich (1980: 21) points out, such emotive interjections are a deliberate part of Heyne's pedagogical strategy.
} 
introductions to each work in which Heyne first defines the general character of the genre (bucolic, didactic, epic), then moves on to discuss how Virgil's poetry manifests its particular character in relation to each. ${ }^{21}$ The result is a self-reinforcing structure, whereby critical points made in general terms in the prefaces are returned to and illustrated against the poems themselves in the individual notes.

A similar reinforcing function is served by what must count as Heyne's most striking formal innovation in the volumes (II and III) containing his commentary upon the Aeneid. This is the addition of a series of excursuses (more than one hundred in total), varying from one paragraph to more than twenty pages in length, and appended to each of the books. Although sometimes keyed to particular lines of the text, these excursuses allowed for more expansive discussion of points addressed only briefly in the notes, and cross-references from the running commentary to the excursuses (and indeed, from the excursuses to the various prefatory essays) are frequent. The longest are those in which Heyne demonstrates both the poet's and his own doctrina in uncovering Virgil's sources or in illuminating Roman and Latin cultural traditions. Examples are the lengthy and meticulous discussion of postHomeric traditions of about Trojan War which occupies the first excursus to Book 2 ('De auctoribus rerum Trojanarum', Heyne 1787-89 II: 267-89), the essay on 'Veteris Italiae origines, populi et fabulae ac religionis' appended to Book 7 (III: 136-48) or the treatment of heroic geography presented at the end of Book 2 (III: 416-25). Others serve the goal of aesthetic education by enabling holistic treatment of recurrent motifs and themes. For example, in the first excursus appended to Book 1 (on line 4: 'vi superum, saevae memorem Junonis ob iram') Heyne offers a concise yet thorough discussion of Juno's opposition to Rome's foundation throughout Virgil's twelve books, demonstrating how the theme of Juno's

21 'De Carmine Bucolico' and 'Prooemium in Georgica', Volume I; 'De carmine epico Virgiliano', Volume II. See Atherton 2006: 81-6. 
divine displeasure unifies the Aeneid from start to end and lends it the 'gravitas' appropriate to epic. In another he considers the connotations of the term 'pius' applied to Aeneas as an epithet 'Homerico more' and suggests that the poem as a whole reveals it to have two main connotations, indicating Aeneas's filial piety and his concern for his household gods. In both cases the excursus enables Heyne to treat issues in more depth and with more connection than an individual note would allow, without distracting the cursory reader with excessive quantities of annotation under the text.

Initial reception of Heyne's Virgil was mixed. Negative reactions are canvassed by Heidenreich (2006: 141-5), who takes a neutral review in the Göttingische Anzeigen von gelehrten Sachen and a decidedly lukewarm one in Nova acta eruditorum as indicating that the scholarly audience was perturbed by his attempt to link the demands of scholarship and aesthetic education. Gradually, however, Heyne's commentary began to be cited as a source of authoritative discussions of Roman realia. From the perspective of the eighteenth century overall, the Virgil was the most successful of Heyne's commentaries. It went through three editions by 1800 , and the pocket version ( 2 vols) produced in 1779-80 provided the basis of school editions for much of the following century. ${ }^{22}$ It was applauded most of all literary figures across Europe, whose reactions have been discussed by Atherton (2006: 74-88) and Haynes (2010: 425-6), and among whom Heyne became something of an academic celebrity. To pick one example from many, here is Thomas Carlyle writing about Heyne some fifteen years subsequent to his death:

By the general consent of the learned in all countries, he seems to be acknowledged as the first among recent scholars; his immense reading, his

\footnotetext{
${ }^{22}$ Haase (2002: 176-80) lists no fewer than thirty-eight editions or reprints 'nach Heynes Ausgabe' published between 1818 and 1893, in places ranging from Leipzig and London to Paris and Turin. The fourth edition, revised by Eberhard Wagner, appeared in 1830-33 in London.
} 
lynx-eyed skill in exposition and emendation are no longer anywhere controverted; among ourselves his taste in these matters has been praised by Gibbon, and by Parr pronounced to be 'exquisite'. In his own country Heyne is even regarded as the founder of a new epoch in classical study; as the first who with any decisiveness attempted to translate fairly beyond the letter of the classics, to read in the writings of the Ancients, not their language alone, or even their detached opinions and records, but their spirit and character, their way of life and thought. (Carlyle 1860 [1828]: 359)

\section{Heyne's Iliad (1802)}

Carlyle's claim that Heyne's works were universally acclaimed may only be maintained, however, by overlooking the reception of the last and most ambitious of his commentaries on classical authors. It was in 1802 that Heyne's Iliad, the projected first part of his complete edition of the Homeric poems, was finally published in Leipzig and London. As the septuagenarian author explained (1802 I: x), it had been in preparation for some twenty years. Its gestation was arguably longer than this, however, for Heyne had been teaching the Iliad and Odyssey at Göttingen since the 1760s and had first set out his vision of what such an edition demanded in an open letter to a former student, Thomas Christian Tychsen, in $1783 .^{23}$

\footnotetext{
${ }^{23}$ The first reference to Heyne teaching the Iliad at Göttingen occurs in the lecture list for winter semester 1766; see Haase 2002: 181. The epistle to Tychsen gives clues as to why Heyne did not proceed directly to Homer after finishing his Virgil, for he states gloomily that 'fatendum est, ne viam quidem ad operam hanc suscipiendam adhuc esse satis instructum, et superesse tam multa tamque varia constituenda, antequam ad novam Homeri recensionem animo et studio designandam accedere liceat, ut res facile unius hominis et annos et vires sit supernatura' (1783: viii).
} 
Many of the other commentaries that issued from his pen in the 1780s and 1790s (Proclus, pseudo-Apollodorus - perhaps even the second Pindar) may be seen as explorations of ancient Greek mythology preparatory to his Homeric endeavours.

The Iliad, which was dedicated to the 'genius' of the Georgia Augusta, represented the culmination of Heyne's academic career. Although it had certain similarities in format and approach with the Virgil, it was still more ambitious in scope. Heyne aimed at nothing less than to unite in one edition all the ancient materials to which a learned reader might have recourse in order to interpret the poem: not merely variant readings, but also the glosses of scholiasts and other ancient commentators. (Heyne 1802 I: viii). A jewel in the crown of Heyne's edition was his restoration (in an apparatus rather than in the text) of the Homeric digamma, carried out with the aid of Richard Bentley's own study copy, which had been loaned to him by as Trinity College, Cambridge. Beyond this, he also proposed to include critical discussions of the most significant recent scholarship on Homer, summarising and adjudicating current debates over Homeric diction, the poems' transmission history and, most vexed of all, the question of their original authorship and unity.

To collect all this material required exploiting the international correspondence networks built up over the course of his long tenure at Göttingen, as well as delegating tasks of collation and analysis to former students, seminarists, and other collaborators (Heyne $1802 \mathrm{I}$ : $\mathrm{x}-\mathrm{xxii})$. To accommodate it, Heyne again adopted the mixed format of lemmatized commentary ('brevis annotatio') and longer 'observationes'. While the first edition of Heyne's Virgil had occupied only four volumes, his Iliad stretched to eight, of which two contained the text with brief notes, one a revision of the Latin translation from the ErnestiClarke edition of 1759, and five variae lectiones and critical excursuses on topics ranging from Greek particles and Homeric dialect to Achaean battle tactics and the poems' transmission history. It appeared simultaneously in Leipzig and London, and both author and 
booksellers clearly hoped that it would ape the success of the Virgil published some four decades before.

It was, however, to meet with a very different reception, for a bitter campaign against the Homer edition and its author was waged through a number of periodicals. Foremost among these was a review of Brobdingnagian proportions, which ran across sixteen issues of the Jena Allgemeine Literaturzeitung in May $1803 .{ }^{24}$ Behind it were Friedrich August Wolf and Johann Heinrich Voss, two former students who had strong personal and professional reasons for disaffection with their teacher. Aided and abetted by Heinrich Karl Eichstädt, they set about demolishing Heyne's reputation by means of swingeing criticism of the plan, methods and execution of his Homer. ${ }^{25}$

As Volkmann (1874: 120) observes, the length of this review is out of all proportion to its positive contribution to scholarship. Its longest sections, very likely by Wolf and Voss respectively, dissect the failings of Heyne as a textual editor and rehearse objections to his construals of Homeric geography and mythology. Heyne is also repeatedly taken to task for the redundancy of his explanations, for his imperfect understanding of Homeric dialect, and for basic grammatical errors in Greek and Latin. Sometimes the criticisms are justified, as when Heyne is skewered for neglect of the Greek infinitive rule in his gloss on Il.1.78 ([Voss,

${ }^{24}$ I focus below on the $A L Z$ review, which occupied some 120 columns. Somewhat broader discussions of Heyne's detractors' campaign are given in Volkmann 1874: 115-45 and Friedrich 1980: 27-31.

${ }^{25}$ Voss gleefully recounts the history of his falling out with Heyne in his Antisymbolik (1826 II: 1141). For Wolf's dispute with Heyne in the mid-1790s over priority in the theses advanced in his Prolegomena ad Homerum, see Harloe 2013: 137-59. Eichstädt was a classicist and professor at the University of Jena, a rival intellectual centre to Göttingen, and was closely associated with the ALZ. 
Wolf and Eichstädt] 1803: 310-11); elsewhere one feels that bile and vindictiveness are the main force behind the criticisms. Along the way, however, a number of serious points are made about failings in Heyne's fulfilment of the commentator's task.

Some of the most pertinent of these are made in the review's central section on 'Worterklärung' (302-37). Besides identification of Heyne's errors on particular points of interpretation, the reviewers make two more global criticisms: of the diffuse and rambling character of many of his explanations, and of the confused order of his exposition. Both must have been cutting to Heyne, who as we have seen prided himself upon the concision of his commentary and its appropriateness to different audiences. Yet there is a certain justice in the reviewers' comments. Let us consider one example: their complaint, a propos of Heyne's note on $\mathrm{Il} .1 .225$, about about the triviality and generality of his glossing of $\kappa v v \omega ́ \eta \varsigma$ and cognates as 'insults in the heroic speech of antiquity' ('Schimpfwörter aus der heroischen Sprache des Alterthums', [Voss, Wolf and Eichstädt] 1803: 321-3). This is rather unfair to Heyne, who comments on the entirety of the line (oivo $\beta \alpha \rho \dot{\varepsilon} \varsigma, \kappa v v o ̀ \varsigma ~ o ̈ \mu \mu \alpha \tau^{\prime}$ '̌ $\chi \omega v, \kappa \rho \alpha \delta i \eta \eta v$ $\delta$ ’è $\lambda \dot{\alpha} \varphi o l o$ ), and whose comment ('Ex antiquo sermone, et cum libertate linguae priscorum heroum dicta sunt. Vecordem, impudentem et imbellem voluit dicere') makes a serious point, pursued elsewhere in the notes, about differences between Homeric and modern manners. ${ }^{26}$ Yet the critics are right to note the difficulty any reader would encounter in locating Heyne's discussion of this topic. Neither the first occurrence of $\kappa v v \tilde{\omega} \pi \alpha$ at 1.159 nor Helen's castigation of herself as $\kappa v v \tilde{\omega} \pi \iota \varsigma$ at 3.180 are given comment or cross-reference, and the reader seeking to appreciate Heyne's overall position on Homeric insults must cast about between different volumes and kinds of notes. ${ }^{27}$

\footnotetext{
${ }^{26}$ See for example his comments on 1.39 .

${ }^{27}$ An index verborum, such Heyne had included in the Tibullus and Virgil and would have mitigated some of these problems, was only added to the Homer ten years after his death (Graeffenhan 1822).
} 
These complaints are sharpened into the greatest overall criticism of Heyne's commentary: its lack of suitability to different audiences. It is hard not to sympathise with Voss and Wolf's portrayal of the student or amateur reader bewildered by the five fat volumes of critical observations and, just where they might expect an apparatus of variae lectiones, the alien forms of the digamma. For 'the more exacting scholar' ['der strengere Gelehrte'], by contrast, the anthology of ancient and modern criticism in the final five volumes appears to have been selected arbitrarily and without justification. The result is a work with which neither the student, nor the scholar, will be satisfied $(1803,243-4)$.

It might be tempting to dismiss such criticisms as merely identifying failings in Heyne's execution of the commentator's task. As he himself had pleaded (and as the reviewers gleefully recalled), his Iliad was the product of interrupted study over a number of decades, finished off in rare moments snatched between teaching and administrative duties at the Georgia Augusta. ${ }^{28}$ We should also perhaps ask whether, in attempting a commentary on the Iliad, Heyne chose a medium appropriate to his ends. Kenneth Haynes (2010) has recently positioned Heyne's commentaries within a narrative of a 'major shift in emphasis from the normative to the representative' notions of the classical which took place in the later eighteenth and early nineteenth centuries. ${ }^{29}$ As scholars and intellectuals began to regard ancient works not as a source of moral, political and aesthetic principles applicable across time, but instead as vestiges of admired, yet individual and potentially inimitable historical

\footnotetext{
${ }^{28}$ Heyne's devotion to his administrative tasks is legendary. See in particular the contributions to Universität Göttingen 1980.

${ }^{29}$ This narrative does not, of course, originate with Haynes. For an insightful overview of the new scholarship of this era, which presents it as characterised by (among other features), 'the will to replace the text ... to dissolve the texts before them in order to recreate something lost', see
} Grafton 1983, especially 181-2. For further relevant bibliography see Harloe 2013: xv. 
cultures, 'a new significance [was] attached to culture, national character, and historical explanation' even in the case of canonical texts (Haynes 2010: 422). For Haynes, the beginnings of this change are already apparent in Heyne's attempt to interpret Virgil's Aeneid 'with constant and extensive reference to the particularities of Roman life and thought' (424). This is to some extent true, but it is the Homeric poems which present the reader with the most seductive, deeply imagined and apparently coherent heroic 'world'. ${ }^{30}$ The eight volumes of Heyne's Iliad were his attempt to do justice to this sense of Homeric epic not only (or perhaps even primarily) as a literary work, but as the expression and trace of a past historical culture.

Numerous challenges attended this effort—and perhaps even doomed it from the outset. As Heyne himself recognised, the range of relevant material far exceeded what could be collected and surveyed by one man. ${ }^{31}$ He nevertheless attempted to unite in one edition all that might be relevant to the historical and literary appreciation of the Iliad, as well as to take stock of the extraordinary efflorescence of Homeric studies, stimulated from many different directions (biblical studies, travel literature, archaeology), among the scholars and intellectuals of his day.

Today we are accustomed to encounter such 'state of the field' discussions in review articles rather than commentaries on literary texts, and Heyne might have been better off reserving such material for a discourse before the Academy of Sciences or essays in the Göttingische Anzeigen. Yet if his aspiration to account for contemporary scholarship doomed this commentary to appear almost instantly as a failed attempt to keep up with a moving

\footnotetext{
${ }^{30}$ Haynes acknowledges that Heyne's contemporaries saw the Virgil's aesthetic discourse, rather than its antiquarian and historical content, as his main innovation. See Heidenreich $(2006,144-5)$ for discussion.

${ }^{31}$ Heyne 1783; see n. 23 above.
} 
target, quite other challenges attended his efforts to adapt the commentary format to giving a comprehensive picture of the Homeric world. I have suggested that in the case of Heyne's Aeneid, a mixed format of 'brevis annotatio' and excursuses provided a means of overcoming to some extent the restrictions of lemmatic commentary and bringing attention to the construction and context of the poem as a whole, without unduly disturbing the reading experience or sacrificing altogether the commentator's traditional close focus on individual lines and passages. When it came to treating a text not so much as a literary masterwork, but rather as a window onto a long-past culture, the same approach generated diffuseness and prolixity rather than clarity, confusion rather than a self-reinforcing structure. Was the issue simply Heyne's lack of time and attention and his inadequate mastery of the technical skills of the philologist, as his reviewers would have us believe? Or was there something more fundamentally incongruous about the endeavour to adapt the format of the commentary — that most traditional and text-focused of scholarly formats - from illuminating a text to providing a complete and coherent picture of a lost culture and a tradition? It is, as Volkmann (1874: 117) suggests, unfair to expect a commentator to display monographic mastery and thoroughness on every linguistic, literary and historical-contextual topic relevant to his text. But it is perhaps no accident that it was the extended essay and the monograph, rather than the commentary, which developed into the more usual formats for the kind of systematic exposition towards which Heyne was striving. ${ }^{32}$

\section{Bibliography}

\section{WORKS BY HEYNE}

(1755), Albii Tibulli quae extant carmina, novis curis castigata illustrissimo domino Henrico comiti de Brühl inscripta (Leipzig).

\footnotetext{
${ }^{32}$ For highly relevant discussion of a nineteenth-century example (Karl Otfried Müller's Eumenides edition of 1833), see Most 1998, esp. 358-66.
} 
$4^{\text {th }}$ edn: (1817), Albii Tibulli Carmina libri tres, cum libro quarto Sulpiciae et aliorum... editio quarta nunc aucta notis et observationibus Ern. Car. Frid. Wunderlichii (Leipzig).

(1783), 'Epistola ad V. Cl. Tho. Chr. Tychsen Holsatum, obiter consilia de nova Homeri editione agitantur', in Tychsen (1783), v-xxiv.

1767-75, P. Virgilii Maronis opera varietate lectionis et perpetua adnotatione illustrata,4 vols (Leipzig).

$2^{\text {nd }}$ edn: (1788-9, P. Virgilii Maronis opera varietate lectionis et perpetua adnotatione illustrata. Accedit index uberrimus, 4 vols (Leipzig).

(1802), Homeri carmina cum brevi annotatione. Accedunt variae lectiones et observationes veterum grammaticorum cum nostrae aetatis criticae, 8 vols (Leipzig and London).

\section{SECONDARY LITERATURE}

Anon. [Gesner?] (1755), [Review of Heyne, Albii Tibulli quae extant carmina], Göttingische Anzeigen von gelehrten Sachen 45 (14 April), 409-11.

Anon. (1767), [Review of Heyne, P. Virgilii Maronis opera... Tomus prior], Göttingische Anzeigen von gelehrten Sachen 32 (14 March), 249-53.

Atherton, G. (2006), The Decline and Fall of Virgil in the Eighteenth Century: The Repressed Muse (New York).

Blaschke, K. and Lau, F. (1959), 'Ernesti, Johann August", in Neue Deutsche Biographie 4: 604-5 ( http://www.deutsche-biographie.de/pnd100804500.html, accessed 31 July 2013).

Broekhuizen, Joan van (1708), Albii Tibulli equitis Rom. quae exstant, ad fidem veterum membranarum sedulo castigata... (Amsterdam).

Bursian, Conrad (1883), Geschichte der classischen Philologie in Deutschland : von den Anfängen bis zur Gegenwart, 2 vols (Munich).

Calder, W.M. and Schlesier R. (eds.), Zwischen Rationalismus und Romantik. Karl Otfried Müller und die antike Kultur (Hildesheim).

Carlyle, T. (1860 [1828]), 'The Life of Heyne', in Critical and Miscellaneous Essays: Collected and Republished, 4 vols., vol 1 (Boston), 327-362.

Clark, W. (2006), Academic charisma and the origins of the research university (Chicago and London).

Ernesti, J.A. (1737-9), M. Tullii Ciceronis opera omnia. Accedit varietas lectionis... cum singulorum librorum argumentis... et Clavis Ciceroniana. 4 vols (Leipzig). 
Ernesti, J.A. (1762), Opuscula oratoria, orationes, prolusiones et elogia. Accessit Narratio de Jo. Matthia Gesnero ad Davidem Ruhnkenium V.C. Leiden.

Ernesti, J.A., (1794), Opuscula varii argumenti (Leipzig).

Ernesti, J.A., (1801) [1773] C. Cornelii Taciti opera (Leipzig).

Fornaro, S. (2004), I Greci senza lumi. L'antropologia della Grecia antica in Christian Gottlob Heyne (1729-1812) e nel suo tempo (Göttingen).

Friedemann, F.T. (1828), Dav. Ruhnkenii orationes, dissertationes et epistolae, cum suis aliorumque annotationibus (Braunschweig).

Friedrich, R. (1991), Johann Matthias Gesner: Sein Leben und sein Werk (Roth).

Friedrich, W-H. (1980), 'Heyne als Philologe’, in Universität Göttingen 1980, 15-31.

Gesner, J.M. (1738), Schul-Ordnung vor die Churfürstl. Braunschweig-Lüneburgische Lande... (Göttingen).

Gesner, J.M. (1745a) [1735], 'In T. Liuium Lipsiae MDCCXXXV editum Praefatio', in Gesner 17435, vol. 7, 289-307.

Gesner, J.M. (1743-5), Opuscula minora varii argumenti, 8 vols (Breslau).

Gesner, J.M. (1756), Kleine Deutsche Schriften (Göttingen and Leipzig).

Gesner, J.M. (1759), Cl. Claudiani quae exstant varietate lectionis et perpetual adnotatione illustrata (Leipzig).

Graeffenhan, E.A. (1822), Homeri carmina curante C.G. Heyne. Tomus Nonus indices continens (Leipzig).

Graf, F. (1987) Griechische Mythologie : eine Einführung, 2nd edn (Munich).

Grafton, A. (1983), 'Polyhistor into Philolog: Notes on the Transformation of German Scholarship, 1780-1850', History of Universities 3 (1983), 159-92.

Grafton, A. (2010), 'Heyne, Christian Gottlob', in Grafton, Most and Settis 2010, 436-7.

Grafton, A., Most, G. and Settis, S. (2010), The Classical Tradition (Cambridge, MA and London).

Haase. F-A. (2002), Christian Gottlob Heyne (1729-1812). Bibliographie zu Leben und Werk. Gedruckte Veröffentlichunge, Zeitgenössische Schriften zu einer Rezeption, Forschungsliteratur (Heidelberg).

Heeren, A.H.L. (1813), Christian Gottlob Heyne. Biographisch dargestellt (Göttingen).

Harloe, K. (2013), Winckelmann and the Invention of Antiquity: History and Aesthetics in the Age of Altertumswissenschaft (Oxford). 
Haynes, K. (2010), 'Classic Vergil', in Joseph Farrell and Michael C. J. Putnam (eds.), A Companion to Vergil's Aeneid and its Tradition (Chichester), 421-34.

Heidenreich, M. (2006), Christian Gottlob Heyne und die alte Geschichte (Munich).

Heinze, N. and Schrevel, C. (1665), Cl. Claudiani quae exstant,... Accedunt selecta variorum comm. (Amsterdam).

Kenney, E.J. (1974), The Classical Text: Aspects of Editing in the Age of the Printed Book (Berkeley, Los Angeles and London).

Legaspi, M. (2008), 'The quest for classical antiquity at eighteenth-century Göttingen', History of Universities, 24 (2), 139-72.

Legaspi, M. (2010), The Death of Scripture and the Rise of Biblical Studies (Oxford).

Leventhal, R (1986), 'The Emergence of Philological Discourse in the German States 1770-1819', Isis 77, 243-60.

Leventhal, R. (1994), The disciplines of interpretation : Lessing, Herder, Schlegel and hermeneutics in Germany, 1750-1800 (Berlin).

Maltby, R. Tibullus: Elegies. Text, Introduction and Commentary (Cambridge).

Most, G.W. (1998), 'Karl Otfried Müller's Edition of Aeschylus' Eumenides', in Calder and Schlesier (eds.) (1998), 349-73.

Most, G.W (2002) (ed.), Disciplining Classics - Altertumswissenschaft als Beruf (Göttingen).

Paulsen, F. (1885), Geschichte des gelehrten Unterrichts auf den deutschen Schulen und

Universitäten vom Ausgang des Mittelalters bis zur Gegenwart. Mit besonderer Rücksicht auf den klassischen Unterricht (Leipzig).

Pfeiffer, R. (1976), History of Classical Scholarship from 1300 to 1850 (Oxford).

Rehm, W. (1957), Winckelmann: Briefe. Kritisch-historische Gesamtausgabe, vol. 4 (Berlin).

Sandys, J.E. (1908), A History of Classical Scholarship Volume III: The Eighteenth Century in Germany, and the Nineteenth Century in Europe and the United States of America (Cambridge).

Schindel, U. (1964), 'Gesner, Johann Matthias', in Neue Deutsche Biographie 6 (1964), 348-349 (http://www.deutsche-biographie.de/pnd118717146.html, accessed 31 July 2013).

Slater, D.A. (1912), 'Was the fourth eclogue written to celebrate the marriage of Octavia to Mark Antony? - A literary parallel', Classical Review 26, 114-119.

Timpanaro, S. (2005), The Genesis of Lachmann's Method, tr. G. W. Most (Chicago). 
Tychsen, T.C. (1783), Commentatio de Quinti Smyrnaei Paralipomenis Homeri, qua nova carminis editionem indicit Thomas Christian Tychsen. Cum epistola C.G. Heynii in qua obiter de nova Homeri editione agitantur (Göttingen).

Universität Göttingen (1980), Der Vormann der Georgia Augusta. Christian Gottlob Heyne zum 250. Geburtstag: sechs akademische Reden (Göttingen).

Vöhler, M. (2002), 'Christian Gottlob Heyne und das Studium des Altertums in Deutschland', in Most 2002, 39-54.

Volkmann, R. (1874), Geschichte und Kritik der Wolf'schen Prolegomena zu Homer (Leipzig).

Volpi, G.A. (1749), Albius Tibullus, eques Romanus...novus commentarius diligentissimus (Padua).

[Voss, J.H., Wolf, F.A. and Eichstädt, H.K.] (1803), [Review of C.G. Heyne (ed.), Homeric carmina), Allgemeine Literatur Zeitung 123-141 (2-13 May), 241-390.

Voss, J.H. (1826), Antisymbolik, 2 vols (Stuttgart).

\section{Abstract}

This chapter discusses the pedagogic and scholarly priorities that informed Heyne's commentaries on Tibullus (1755), Virgil (1767-75) and Homer (1802), as well as their initial critical reception. Like those of his teachers, Gesner and Ernesti, Heyne's works eschew detailed textual scholarship in favour of aesthetic and historicizing appreciation of literary works as wholes. Their formal innovations - most notably the relegation of advanced philological discussions to endnotes and the inclusion of excursuses on significant historical and cultural questions - are an attempt to tailor a traditional format to the demands of an Enlightened age and the cultural-historical interests of the new Altertumswissenschaft. The chapter discusses their contrasting critical receptions in order to raise questions about the viability of Heyne's endeavours to make a traditional medium fit new concerns.

Keywords

Christian Gottlob Heyne; Altertumswissenshaft; Enlightenment; German commentaries; Virgil; Tibullus; Homer; aesthetics; commentary layout 
